\title{
El proceso de fatiga del hormigón y su influencia estructural
}

\section{The fatigue process of concrete and its structural influence}

\author{
C. Zanuy ${ }^{(*)}$, L. Albajar(*), P. de la Fuente(*)
}

Recepción/Received: 8-IX-09

Aceptación/Accepted: 3-II-10

Publicado online/Online publishing: 2-VIII-10

RESUMEN

La fatiga del hormigón está gobernada por un proceso de microfisuración interna que tiene como resultado macroscópico la modificación de las propiedades mecánicas, en particular, la reducción de la rigidez y el crecimiento de las deformaciones totales y residuales en función del nivel de la tensión. La influencia de este proceso en el comportamiento de elementos estructurales es compleja, porque éstos desarrollan una progresiva redistribución interna de tensiones. Por ello, el uso directo de las curvas S-N lleva normalmente a resultados excesivamente conservadores. En este artículo se presenta un modelo de fatiga del hormigón que incluye el cambio de las propiedades del material y es capaz de obtener tanto la vida a fatiga como la evolución de tensiones y deformaciones. Este modelo se compara con otros modelos normativos existentes y se propone una modificación en los mismos para calcular el número de ciclos resistentes de una forma simple y práctica.

Palabras clave: hormigón, fatiga, propiedades mecánicas, microfisuración, deterioro.

\begin{abstract}
SUMMARY
Fatigue of concrete is a microcracking process leading to the change of the macroscopic material properties. In particular, progressive stiffness decrease and increase of total and residual strains are developed as a function of the number of cycles and the stress level. The influence of the fatigue process on the behaviour of structural members is complex, because a cyclic redistribution of stresses develops within the structure. Owing to this fact, the employ of S- $N$ curves to estimate the fatigue life usually leads to extremely conservative results. In this paper, a fatigue model for concrete is presented accounting for the evolution of the material properties. The model is able to obtain the fatigue life and the evolution of stresses and strains. The results are compared with other available design rules and a modification is proposed to estimate the number of cycles to failure in a simple way for the engineering practice.
\end{abstract}

Keywords: concrete, fatigue, mechanical properties, microcracking, damage.

(*) Universidad Politécnica de Madrid (Madrid, España). 


\section{INTRODUCCIÓN}

La fatiga se define como la rotura de un material debido a la actuación de una carga repetida, siendo el valor máximo de esta carga inferior al que produce la rotura estática del material. En términos de Mecánica de la Fractura, la rotura por fatiga se debe al crecimiento de fisuras subcríticas, es decir, la acción repetida conlleva la propagación de alguna fisura, que en sí no conllevaría la rotura estática, hasta que se produce la rotura repentina del material. En los metales $u$ otros materiales con comportamiento lineal en servicio, la vida a fatiga depende fundamentalmente de la oscilación de tensiones, y puede ser descrita mediante las conocidas curvas S-N o de Wöhler, y la propagación de fisuras subcríticas obedece a la ley de Paris (1), según la cual la velocidad de propagación de las fisuras depende de la oscilación de tensiones de una forma lineal en escala doblemente logarítmica.

El hormigón es un material de naturaleza heterogénea, cuyo comportamiento estático es no lineal a partir de tensiones de compresión moderadas (aproximadamente $\left.0,30 f_{c}\right)$. Cuando se somete una probeta de hormigón a una tensión de compresión oscilando cíclicamente entre dos límites, las tensiones de tracción transversales originadas por la heterogeneidad del material causan microfisuras en la matriz de cemento y en el contacto pasta - áridos. La propagación de estas microfisuras hasta que su coalescencia provoca la rotura de la probeta describe el proceso de fatiga del hormigón, que tiene como resultado macroscópico el progresivo deterioro de las propiedades mecánicas del material (2). Al contrario que los materiales con acumulación de daño por fatiga lineal (metales), la fatiga del hormigón depende fundamentalmente del nivel de la tensión $\left(\sigma_{\max } / f_{c}\right)$, y no sólo de la oscilación $(\Delta \sigma)$.

En este artículo se describe el proceso de fatiga del hormigón en compresión, planteando los cambios que tal proceso provocan en las propiedades mecánicas del hormigón, para estudiar después la influencia que ello tiene en elementos estructurales (como vigas armadas). Se plantea la conveniencia de las ecuaciones disponibles en algunas normativas de diseño para analizar la influencia de la fatiga del hormigón frente a la capacidad de un modelo de fatiga presentado por los autores. Para ello, se comparan los resultados que aportan estas ecuaciones y los del modelo de fatiga para reproducir el comportamiento experimental de vigas de hormigón armado sometidas a fatiga.

\section{FATIGA DEL HORMIGÓN: DESCRIPCIÓN Y MODELIZACIÓN}

\subsection{El proceso de fatiga del hormigón}

La fatiga del hormigón es un proceso de microfisuración que se debe a las tensiones de tracción originadas

\section{INTRODUCTION}

Fatigue is defined as the weakening of a material caused by repeating loads whose maximum value is smaller than the static failure load of the material in question. In fracture mechanics terms, fatigue failure is due to the growth of subcritical cracks, i.e., the repeated action induces a crack that would not in itself cause static failure to grow until the material fails abruptly. In metals or other materials with linear in-service behaviour, fatigue life depends essentially on the range of stress intensity, as represented by Wöhler or S-N curves. The propagation of subcritical cracks, in turn, follows the Paris law (1), according to which the crack growth rate depends linearly on the range of stress intensity on a double log scale.

Concrete is a heterogeneous material whose static behaviour becomes non-linear beginning at fairly moderate compressive stress values (approximately $0.30 f_{c}$ ). When a concrete specimen is subjected to compressive stress that fluctuates cyclically between two extremes, the transverse tensile stress generated by the non-uniformity of the material forms microcracks in the cement matrix and at the paste-aggregate interface. In concrete fatigue, whose macroscopic result is the gradual deterioration of the mechanical properties of the material (2), these microcracks propagate to the point where their coalescence induces specimen failure. Unlike materials in which fatigue damage accumulates linearly (metals), concrete fatigue depends not only on the range of intensity $(\Delta \sigma)$, but also and primarily, on the stress level $\left(\sigma_{\max } / f_{c}\right)$.

The present article describes compressive fatigue in concrete, exploring the changes induced in its mechanical properties and the effect of this process on structural members (such as $R C$ beams). The suitability of the equations put forward in some design codes for analysing the effect of concrete fatigue is compared to the features of the fatigue model introduced here by studying the capacity of the various models to predict the experimental behaviour of reinforced concrete beams subject to fatigue.

\section{CONCRETE FATIGUE: DESCRIPTION AND MODELLING}

\subsection{Fatigue in concrete}

Concrete fatigue consists of microcracking in the wake of tensile stress generated in the specimen due to the 
en la probeta como resultado de la heterogeneidad de la microestructura del material. Bennet y Raju (3) estudiaron la distribución de tensiones en la pasta de cemento alrededor de un hueco y en la proximidad de una partícula rígida (árido), comprobando que las tracciones generadas eran las responsables de la microfisuración ante carga repetida (Figura 1). Shah y Chandra (4) confirmaron que, en hormigón de resistencia normal, las microfisuras se forman en el contacto pasta - árido y se propagan después por la pasta de cemento. microstructural non-uniformity of this material.. Studying stress distribution in cement paste both alongside an opening and in the area surrounding a stiff particle (aggregate), Bennet and Raju (3) observed that the stress generated was responsible for microcracking under repeated loads (Figure 1). Shah and Chandra (4) confirmed that in standard strength concrete, microcracks form at the paste-aggregate interface and consequently propagate across the cement matrix.

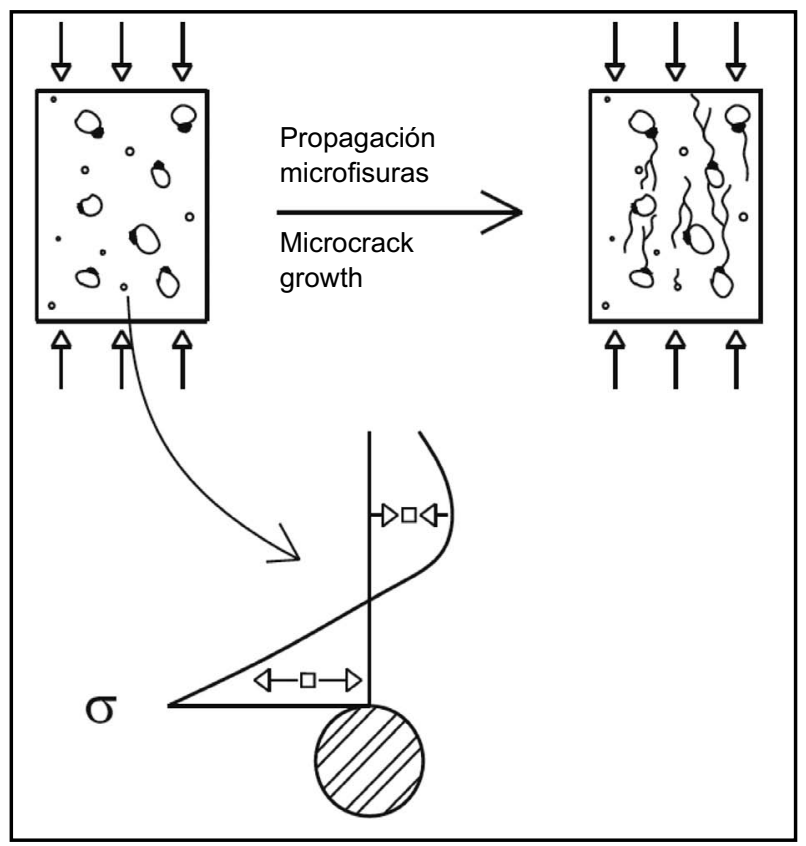

Figura 1. Microfisuración en el hormigón y tensiones transversales en el contacto árido-pasta.

Figure 1. Concrete microcracking and transverse stress distribution at the paste-aggregate contact.

La microfisuración tiene su resultado macroscópico en la Figura 2a: crecimiento de deformaciones irreversibles y reducción de la rigidez. La cuantificación del deterioro de estas variables depende tanto de la tensión máxima como de la mínima $\left(\sigma_{\max } / f_{c}\right.$ y $\left.\sigma_{\min } / f_{c}\right)$, pero su evolución en función del número de ciclos desarrolla tres fases características (Figura 2 b y c). La primera fase se corresponde con la formación de microfisuras en la interfaz árido - pasta y se caracteriza por un deterioro importante de las propiedades del hormigón. Ocupa aproximadamente el $10-15 \%$ de la vida a fatiga. La segunda fase describe la propagación estable de las microfisuras y se caracteriza por una velocidad de crecimiento de la deformación y reducción del módulo constantes. La segunda fase se extiende hasta el $80-90 \%$ de la vida a fatiga. En la última fase tiene lugar la unión de las microfisuras hasta la formación de una macrofisura que rompe la probeta. En la tercerea fase el deterioro del material es también muy importante.
The macroscopic outcome of microcracking, namely an increase in irreversible deformation and a decline in stiffness, is depicted in Figure 2a. The degree of deterioration of these variables depends on the maximum and the minimum stress $\left(\sigma_{\max } / f_{c} y \sigma_{\min } / f_{c}\right)$ values, although deterioration can be divided into three characteristic stages (Figures $2 b$ and $c$ ). In the first stage microcracks form at the aggregate-paste interface, leading to a substantial deterioration in concrete properties. This stage covers approximately $10-15 \%$ of the fatigue life. In the second stage, the microcracks grow steadily, as strain rises at a constant rate and the modulus of deformation declines, likewise at a constant rate. The second stage covers $80-90 \%$ of fatigue life. In the last stage the microcracks converge to form a macrocrack that causes specimen failure. Substantial deterioration also takes place in the material in this third stage. 


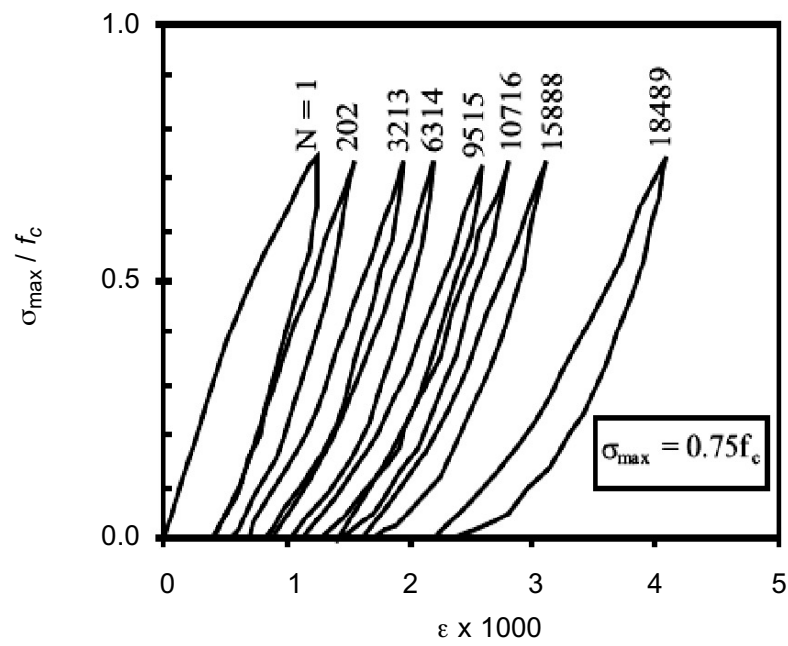

(a)

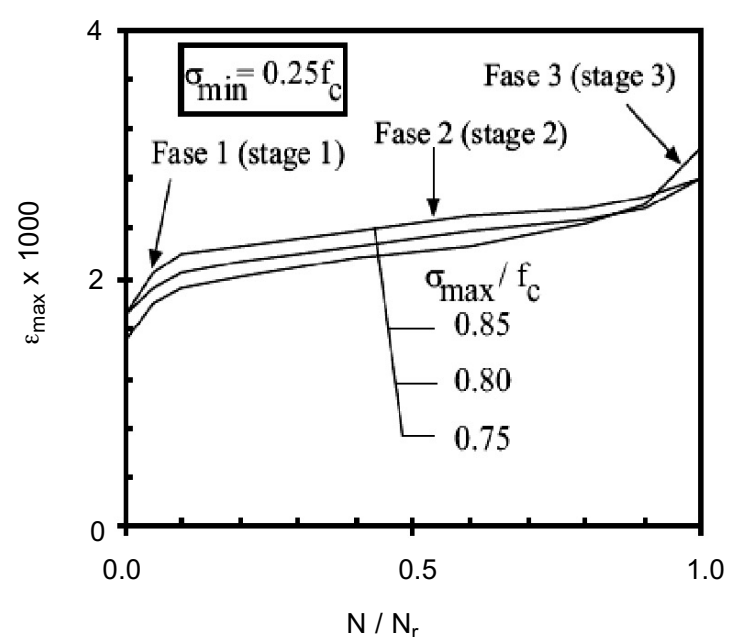

(b)

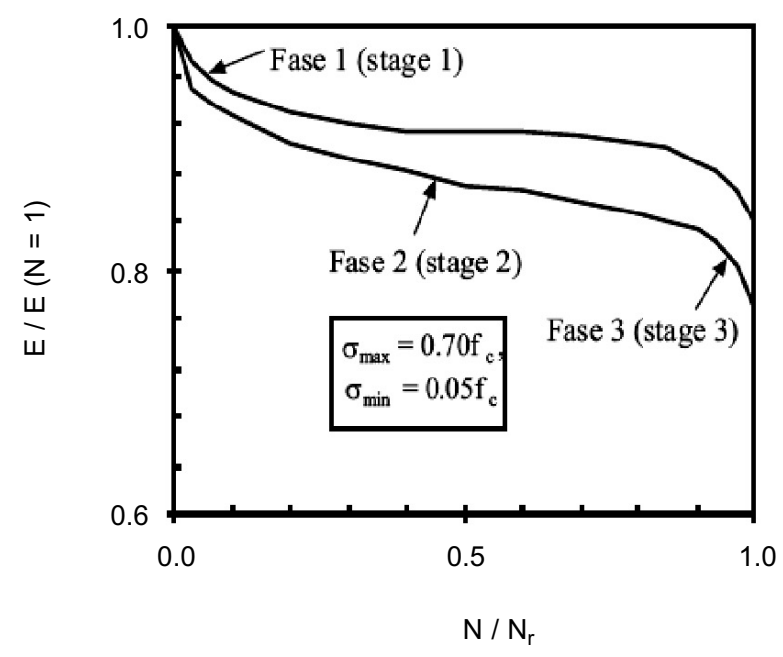

(c)

Figura 2. El proceso de fatiga del hormigón: (a) Evolución de las curvas tensión-deformación, según Holmen (9); (b) evolución de la deformación con el número de ciclos, según Kim y Kim (21); (c) evolución del módulo de deformación con el número de ciclos, según Do et al. (22).

Figure 2. Fatigue process of concrete: (a) Evolution of stress-strain curves, from Holmen (9); (b) strain increase over number of cycles, from Kim and Kim (21); (c) stiffness decrease over number of cycles, from Do et al. (22).

Para describir el número de ciclos resistentes se pueden utilizar unas curvas $\mathrm{S}-\mathrm{N}$ en las que la vida a fatiga $\left(N_{f}\right)$ se representa en función de la tensión máxima $\left(\sigma_{\max } / f_{c}\right)$. La expresión general de la curva S-N del hormigón es la dada por la ecuación [1]:

$$
\log N_{f}=\frac{1-\alpha \frac{\sigma_{\max }}{f_{c}}}{\beta(1-R)^{\gamma}}
$$

Donde $R=\sigma_{\min } / \sigma_{\max } y$ los parámetros $\alpha, \beta, y \gamma$ se indican en la Tabla 1 según diversos autores. En la Figura 3
The number of fatigue cycles can be determined from $S$ $N$ curves, in which the fatigue life $\left(N_{f}\right)$ is plotted against the maximum stress $\left(\sigma_{\max } / f_{c}\right)$. The general expression for concrete $S-N$ curves is given by equation [1]: 


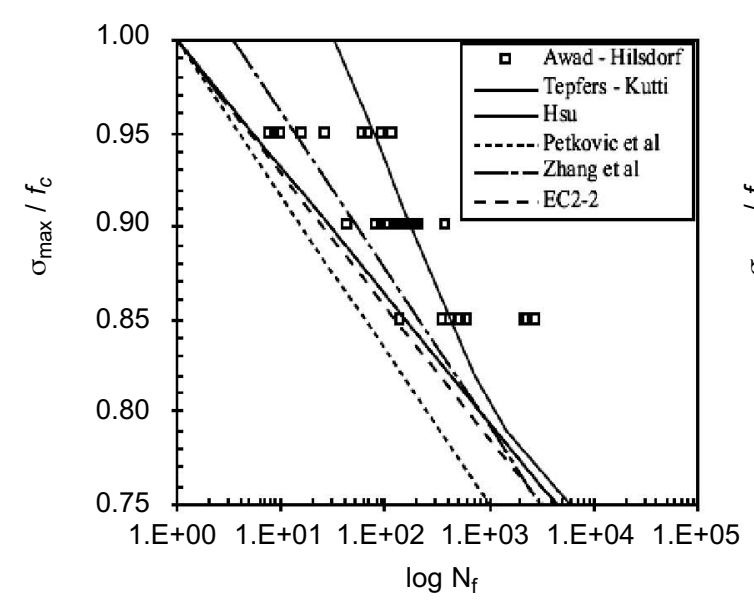

(a)

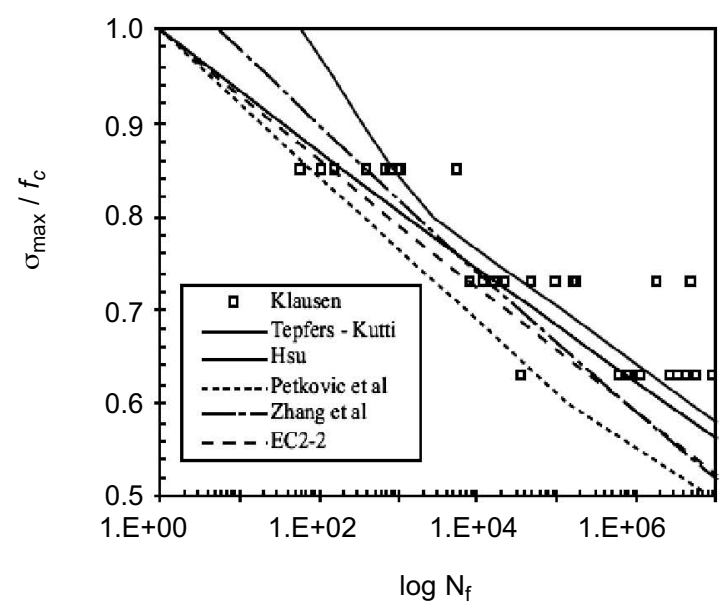

(c)

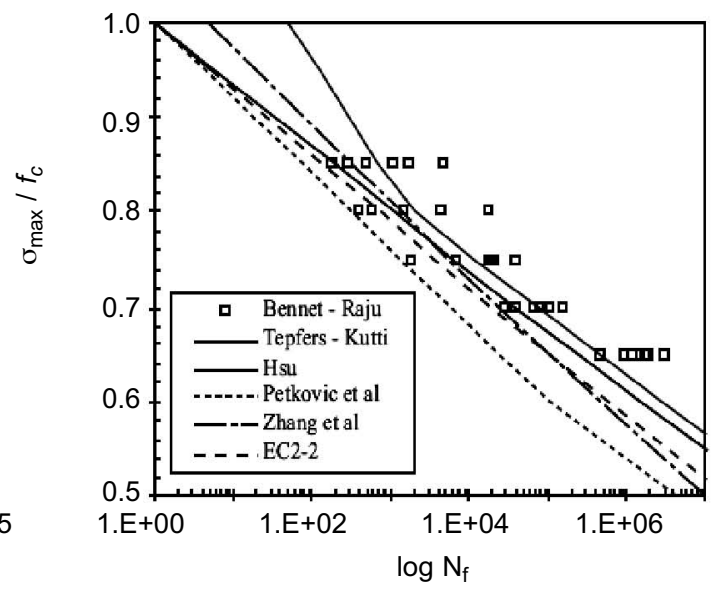

(b)

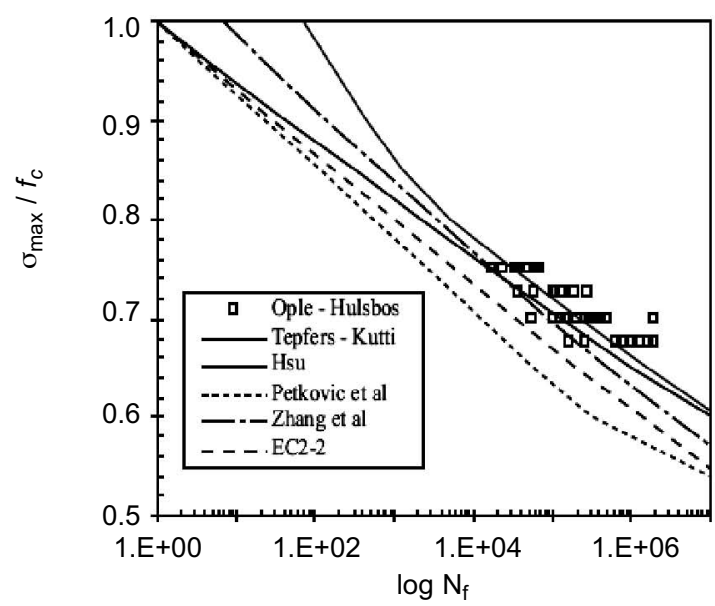

(d)

Figura 3. Comparación de resultados experimentales con las curvas S-N del hormigón: (a) Ensayos de Awad y Hilsdorf (23); (b) Ensayos de Bennett y Raju (3); (c) Ensayos de Klausen (24); (d) Ensayos de Ople y Hulsbos (25).

Figure 3. Comparison of experimental results and S-N curves for concrete: (a) Tests from Awad and Hilsdorf (23); (b) Tests from Bennett and Raju (3); (c) Tests from Klausen (24); (d) Tests from Ople and Hulsbos (25).

se hace una comparación de las formulaciones indicadas, así como las de Hsu (5) y Petkovic et al. (6), con ensayos existentes en la literatura. La formulación de Hsu es algo más compleja, pero es la que habitualmente reproduce más fielmente los resultados experimentales (Figura 3), y se expresa de acuerdo a las ecuaciones [2] y [3]: number of sources. The results of solving these equations and of the expressions proposed by Hsu (5) and Petkovic et al. (6) are compared to the experimental results reported in the literature in Figure 3. Hsu's proposal, while somewhat more complex, ordinarily reproduces experimental results more accurately (Figure 3) than any of the others. It can be expressed according to equations [2] and [3]:

$$
\begin{gathered}
\log N_{f}=\frac{1}{0.133(1-0.779 R)}\left[1.2-0.2 R+0.053(1-0.445 R) \log f-\frac{\sigma_{\max }}{f_{c}}\right], N_{f}<1000 \\
\log N_{f}=\frac{1}{0.0662(1-0.556 R)}\left[1+0.0294 \log f-\frac{\sigma_{\max }}{f_{c}}\right], N_{f}>1000
\end{gathered}
$$


Tabla 1 / Table 1

Parámetros de las curvas S-N del hormigón.

Parameters of $S-N$ curves for concrete.

\begin{tabular}{|c|c|c|c|}
\hline Autor / Author & $\boldsymbol{\alpha}$ & $\boldsymbol{\beta}$ & $\gamma$ \\
\hline Aas-Jakobsen (26) & 1 & 0.0640 & 1 \\
\hline Tepfers-Kutti (27) & 1 & 0.0685 & 0.5 \\
\hline EC2-2 (17) & 1 & 0.0714 & 1 \\
\hline Zhang et al (28) & $0.249 \times 0.92-$ logf +0.796 & 0.0807 & \\
\hline
\end{tabular}

Donde $f$ es la frecuencia en $\mathrm{Hz}$. La ecuación de Petkovic et al. es importante por ser la curva S-N que utiliza el Código Modelo MC90. Su formulación analítica está formada por las ecuaciones [4], [5], [6]:
Where $f$ is frequency in $\mathrm{Hz}$. The Petkovic et al. equation, in turn, is the basis for the S-N curve used in the MC90 Model Code. Its analytical expression is composed of equations [4], [5], [6]:

$$
\begin{gathered}
\log N_{1}=\left[12+16\left(\frac{\sigma_{\min }}{f_{c}}\right)+8\left(\frac{\sigma_{\min }}{f_{c}}\right)^{2}\right]\left[1-\left(\frac{\sigma_{\max }}{f_{c}}\right)\right] \\
\log N_{2}=0.2 \log N_{1}\left(\log N_{1}-1\right) \\
\log N_{3}=\log N_{2}\left[0.3-\frac{3}{8}\left(\frac{\sigma_{\min }}{f_{c}}\right)\right] /\left(\frac{\sigma_{\max }-\sigma_{\min }}{f_{c}}\right)
\end{gathered}
$$

La vida a fatiga es $N_{1}$ si $N_{1} \leq 10^{6}$. Si $N_{1}>10^{6}$ y $\left(\sigma_{\max }{ }^{-}\right.$ $\left.\sigma_{\min }\right) / f_{c} \geq 0,3-3 / 8 \sigma_{\min } / f_{c}$ la vida a fatiga es $N_{2}$. En otro caso es $N_{3}$. En la Figura 3 también se observa claramente la gran dispersión de los resultados experimentales cuando se estudia la fatiga del hormigón. Las comparaciones de la Figura 3 indican que la propuesta de Hsu es la que mejor se aproxima a los valores experimentales medios, mientras que las curvas del EC2-2 y de Petkovic et al. (usada en el MC-90) son las más conservadoras, lo que justifica su empleo en códigos normativos.

\subsection{Modelo de material}

En este apartado se describe el modelo de fatiga del hormigón en compresión propuesto por los autores (7), cuyas capacidades se analizan en el apartado 3 para describir la respuesta de elementos estructurales. El modelo es capaz de reproducir la evolución macroscópica del hormigón con el número de ciclos, para lo que se proponen unas leyes de evolución de la deformación máxima $\left(\varepsilon_{\max }\right)$ y el módulo de deformación $(E)$ con el número de ciclos, que simplificadamente se pueden expresar por medio de las ecuaciones [7] y [8]:
Fatigue life is $N_{1}$ if $N_{1} \leq 10^{6}$. If $N_{1}>10^{6}$ and $\left(\sigma_{\max }-\right.$ $\left.\sigma_{\min }\right) / f_{c} \geq 0.3-3 / 8 \sigma_{\min } / f_{c}$ fatigue life is $N_{2}$. Otherwise, it is $N_{3}$. Figure 3 also clearly shows that the experimental data points for concrete fatigue are widely scattered. Further to the figure, the Hsu proposal provides the closest estimate of the mean experimental values, while the EC2-2 and Petkovic et al. curves (used in MC-90) are the most conservative, which would justify their use in design codes.

\subsection{Proposed model}

This section discusses the fatigue model for concrete under compressive stress proposed in an earlier paper (7), whose ability to predict structural member response is analysed in section 3. The model can reproduce the macroscopic variations in concrete as the number of cycles rises: in simplified form, the laws proposed to relate maximum strain $\left(\varepsilon_{\text {max }}\right)$ and the modulus of deformation $(E)$ to the number of cycles can be expressed by equations [7] and [8]:

$$
\begin{gathered}
\varepsilon_{\max }=\varepsilon_{\max }\left(N / N_{f}\right) \\
E=E\left(N / N_{f}\right)
\end{gathered}
$$


Básicamente el modelo asume que el hormigón tiene un comportamiento lineal dentro de un ciclo de carga, con lo que su respuesta dentro de ese ciclo se obtiene conociendo su módulo $E(N)$ y su deformación remanente $\left(\varepsilon_{\max }(N)-\sigma_{\max } / E(N)\right)$. Las expresiones analíticas completas de [7] y [8] se pueden consultar en (7). Su ajuste se realizó para reproducir las tres fases características del proceso de fatiga (Figura $2 b-c$ ). La forma de las leyes de fatiga se representa en la Figura 4. La ley de evolución de la deformación máxima puede asemejarse a una ley de fluencia si se sustituye el número de ciclos por el tiempo. Si se considera que la deformación de rotura por fatiga viene dada por el criterio de la envolvente (8), la ley de fatiga para la deformación máxima se puede definir completamente por dos parámetros: la deformación de transición entre las fases 1 y 2, y la velocidad de deformación de la segunda fase. A partir de los resultados de los ensayos de Holmen (9), estos dos parámetros se expresan como indican las ecuaciones [9] y [10]:
Basically, the model assumes that concrete behaves linearly within a load cycle, whereby its response within that cycle can be found if its $E(N)$ modulus and residual strain $\left(\varepsilon_{\max }(N)-\sigma_{\max } / E(N)\right)$ are known. Analytical expressions [7] and [8] are described more fully in a previous paper (7). They were fitted to reproduce the three stages that characterise fatigue (Figures $2 b-c$ ). These fatigue law curves are shown in Figure 4. The law of maximum strain can be likened to a law of creep in which time is replaced by the number of cycles. If strain at fatigue failure is assumed to be governed by the envelope criterion (8), the fatigue law for maximum strain can be fully defined by two parameters: the transition strain between stages 1 and 2 and the stage 2 strain rate. Further to Holmen's (9) experimental findings, these two parameters are defined by equations [9] and [10]:

$$
\begin{gathered}
\varepsilon_{\text {max }}\left(N=0.1 N_{f}\right)=\frac{1.18 \varepsilon_{0}}{\sigma_{\max } / f_{c}} \\
\frac{d \varepsilon_{\max }}{d\left(N / N_{f}\right)}\left(0.1 N_{f}<N<0.1 N_{f}\right)=\frac{0.74 \varepsilon_{0}}{\sigma_{\max } / f_{c}}
\end{gathered}
$$

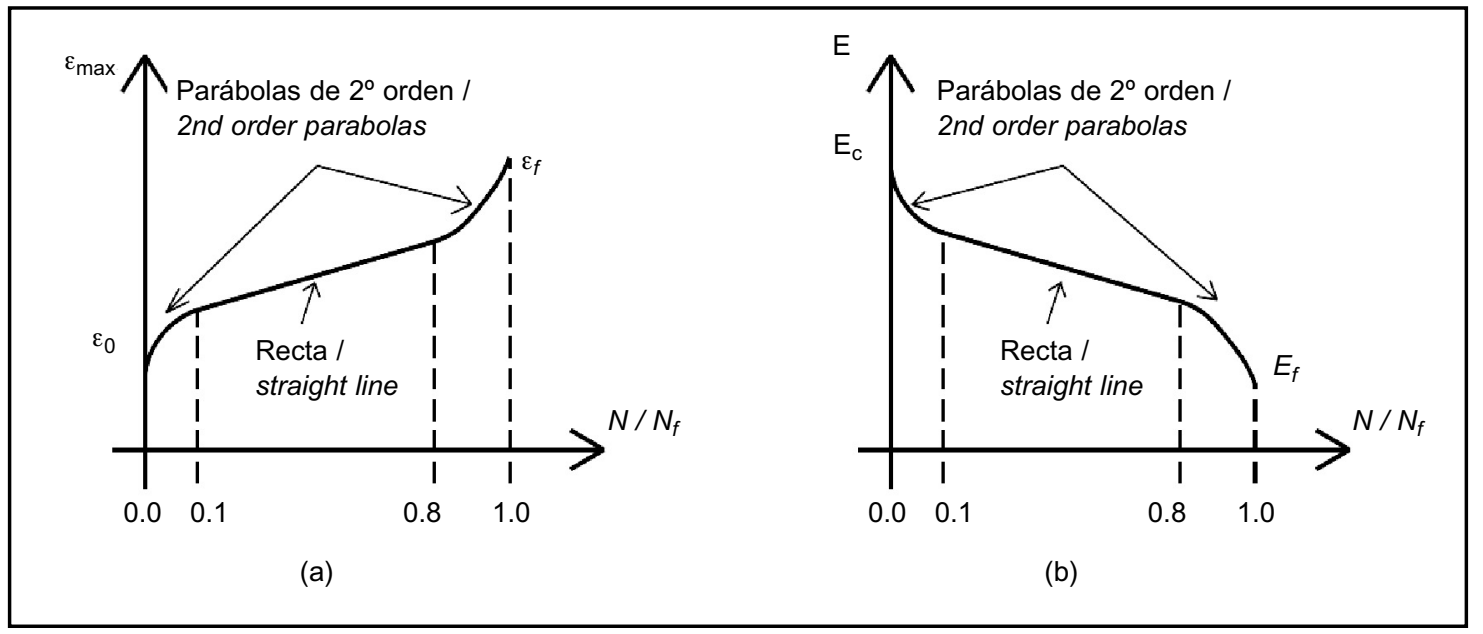

Figura 4. Leyes de evolución por fatiga de: (a) la deformación máxima; (b) el módulo de deformación. Figure 4. Fatigue evolution laws for: (a) the total strain; (b) the modulus of deformation.

Siendo $\varepsilon_{0}$ la deformación máxima en el primer ciclo. La comparación de estas expresiones con una amplia base de datos experimentales recopilada en (7) se representa en la Figura 5a-b. Merece la pena destacar que los distintos símbolos empleados en la Figura $5 a-b$ hacen referencia a campañas experimentales de diferentes autores. Esto incluyó campañas en los que el valor de la tensión mínima era diferente. Se observa que la capacidad de la ecuación [9] para reproducir los datos experimentales es muy buena, existiendo algo más de dispersión respecto a la ecuación [10].
Where $\varepsilon_{0}$ is the maximum strain in the first cycle. The comparison of the curves for these expressions to the data points in a large experimental database compiled in $a$ previous paper (7) is shown in Figures $5 a-b$. The symbols in Figures $5 a-b$ represent the results of experimental campaigns conducted by different authors, in which the minimum stress varied. Equation [9] was observed to provide a close fit to the experimental data, whereas the scatter was somewhat greater in Equation [10]. 


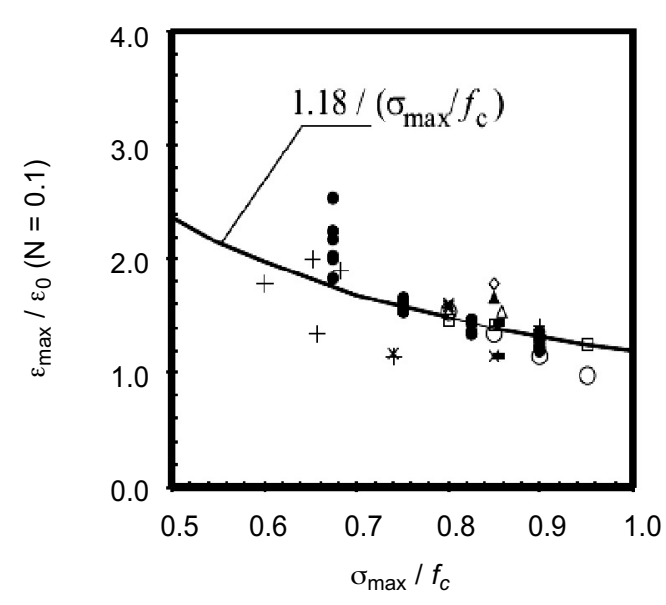

(a)

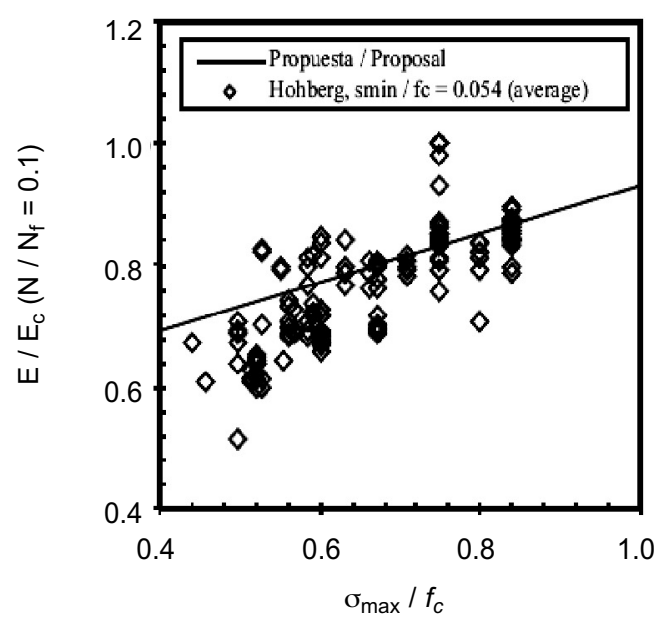

(c)

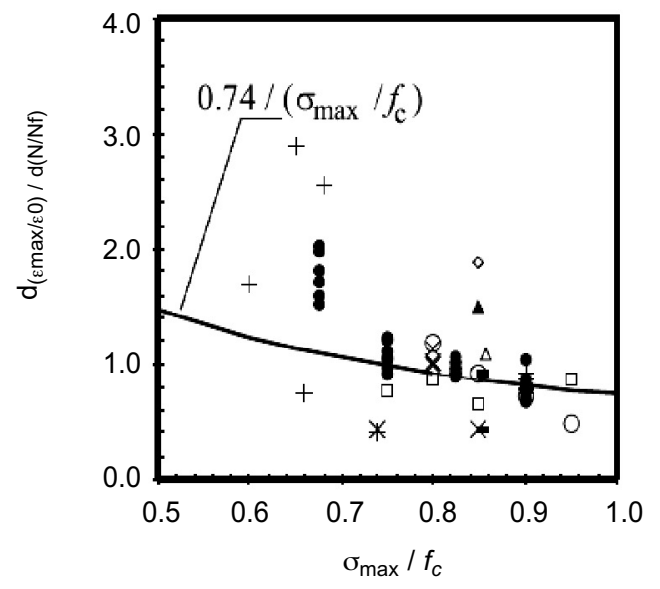

(b)

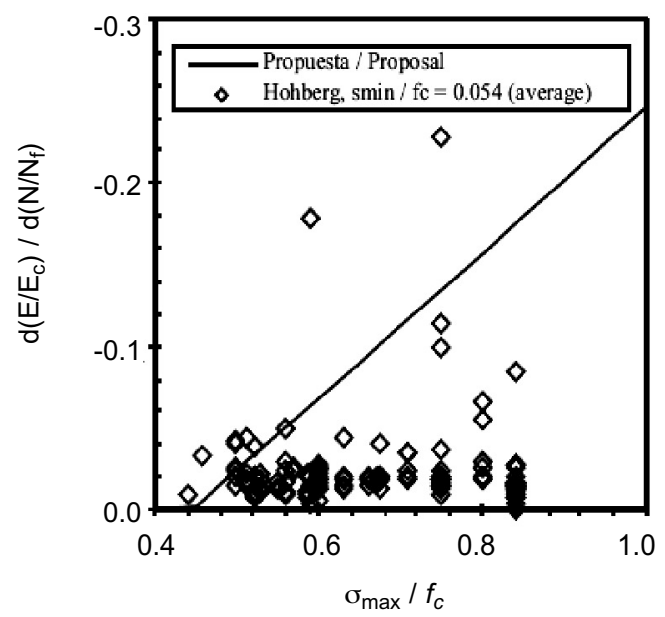

(c)

Figura 5. Comparación de los parámetros propuestos y resultados experimentales de probetas de hormigón: (a) deformación al final de la fase 1; (b) velocidad de deformación en la fase 2; (c) módulo de deformación al final de la fase 1; (d) Velocidad de reducción del módulo en la fase 2.

Figure 5. Comparison of proposed parameters and experimental results from concrete specimens: (a) strain at the end of stage 1; (b) strain rate in stage 2; (c) modulus of deformation at the end of stage $1 ;(d)$ rate of decrease of the modulus of deformation in stage 2.

En cuanto a la evolución de la rigidez, las expresiones propuestas para obtener la rigidez en la transición entre las fases 1 y 2 de fatiga, y la velocidad de reducción del módulo en la segunda fase de fatiga, son las siguientes:

$$
\begin{aligned}
& E\left(N=0.1 N_{f}\right)=\left[\left(0.09+8.19 \frac{\sigma_{\min }}{f_{c}}\right)+\left(0.84-8.19 \frac{\sigma_{\min }}{f_{c}}\right) \frac{\sigma_{\max }}{f_{c}}\right] E_{c} \leq 0.93 E_{c} \\
& \frac{d E}{d\left(N / N_{f}\right)}\left(0.1<N / N_{f}<0.8\right)=\frac{0.25}{0.61-\frac{\sigma_{\min }}{f_{c}}}\left(0.39+\frac{\sigma_{\min }}{f_{c}}-\frac{\sigma_{\max }}{f_{c}}\right) E_{c} \leq 0
\end{aligned}
$$

Donde $E_{C}$ es el módulo de deformación estático. En la Figura $5 \mathrm{c}$-d se comparan los resultados de las ecuaciones [11] y [12] con valores experimentales recientemente obtenidos por Hohberg (10).
The expressions proposed to determine stiffness in the transition from fatigue stage 1 to stage 2 and the rate of modulus decline in fatigue stage 2 are as follows: 


\section{ANÁLISIS DE ELEMENTOS ESTRUCTURALES DE HORMIGÓN SOMETIDOS A FATIGA}

\subsection{Del material a la estructura}

El hormigón es, como se ha indicado, susceptible de sufrir fatiga. Por ello cabe preguntarse cómo se puede evaluar la sensibilidad a fatiga de un elemento de hormigón estructural. Visto desde otro ángulo, dado que hasta la fecha no se ha informado del fallo por fatiga de hormigón en estructuras reales, la pregunta anterior equivale a investigar por qué no se han dado tales problemas y si se está en condiciones de que no se vayan a producir. El procedimiento más sencillo, y ampliamente extendido en las normativas de diseño estructural, está basado en la obtención del número de ciclos resistentes a partir del estado estático de tensiones y las curvas S-N. Este criterio es válido en estructuras metálicas en las que el proceso de daño por fatiga es lineal de acuerdo a la regla de Miner (11). Sin embargo, la fatiga del hormigón es no lineal y depende del nivel de tensiones. Dado que en una estructura la tensión en el hormigón en cada punto es diferente, cada punto tratará de experimentar un incremento de deformación y un daño en su módulo de deformación diferente, de acuerdo a las leyes indicadas en el apartado 2.2. Zanuy et al. (12) han mostrado que este efecto provoca que los elementos de hormigón armado desarrollen un proceso de redistribución de tensiones que hace que los puntos de hormigón más dañados reduzcan la tensión que soportan. Estas tensiones son recogidas por el hormigón no dañado. El método de análisis estructural de (12) hace uso de un nuevo criterio de acumulación de daño por fatiga, que se denomina el número equivalente de ciclos, en lugar de la regla de Miner, usada por los códigos de diseño a pesar de que se ha demostrado que no es válida para el hormigón (13). El número equivalente de ciclos evalúa el daño por fatiga en función de la deformación total acumulada con el número de ciclos. El resultado final es que la vida a fatiga del elemento estructural es mayor que la que se obtiene si se emplea directamente la curva S-N y el estado estático de tensiones sin considerar el proceso de redistribución.

En el siguiente apartado se emplea el procedimiento de análisis propuesto en (12) para estudiar el comportamiento experimental mostrado por vigas de hormigón armado sometidas a fatiga, discutiendo las ventajas e inconvenientes que presenta frente a los métodos tradicionales empleados en las normativas de diseño estructural.

\subsection{Estudio de las vigas de Hashem (14)}

En la literatura científica se pueden encontrar algunas campañas experimentales sobre vigas armadas sometidas a fatiga $(15,16)$. El hecho de que el resultado generalmente

\section{ANALYSIS OF STRUCTURAL CONCRETE MEMBERS SUBJECTED TO FATIGUE}

\subsection{From material to structure}

Concrete, as noted, is liable to fatigue. Consequently, the method for assessing structural concrete member sensitivity to fatigue is a subject of engineering interest. Or to put it another way, since no incidents of concrete fatigue failure in real structures have been reported to date, the question posed is why such problems have not arisen and if the state of the art is in a position to ensure that they will not arise in the future. The simplest and most widely used procedure in structural design standards is based on determining the number of cycles to failure from the static stress state and $S-N$ curves. This criterion is valid in steel structures in which fatigue damage is a linear process that follows Miner's rule (11). Fatigue is not only non-linear in concrete, however, but depends as well on the stress level. Given that stress varies from point to point in concrete structures, each point bears increased strain and a different degree of damage to its modulus of deformation pursuant to the laws cited in item 2.2. Zanuy et al. (12) showed that this effect induces stress redistribution in reinforced concrete members that lowers the stress borne by the most highly damaged points in the concrete. Stress, in effect, is transferred to the undamaged material. In lieu of Miner's rule, used in design codes despite the evidence that is not valid for concrete (13), the structural analysis method described in the aforementioned article applies a new accumulated fatigue damage criterion, denominated the equivalent cycle number. The equivalent cycle number assesses fatigue damage in terms of the total cumulative strain after each cycle. The end result is that the fatigue life of the structural member is longer than estimated when the $S-N$ curve and static stress state are used directly, without taking redistribution into consideration.

The section below describes the use of the analytical procedure proposed in the paper referred to above (12) to study the experimental behaviour exhibited by reinforced concrete beams subjected to fatigue. It also discusses the advantages and drawbacks of that procedure with respect to the traditional methods used in structural design codes.

\subsection{Study of Hashem's beams (14)}

The scientific literature contains a number of experimental campaigns on reinforced concrete beams subjected to fatigue $(15,16)$. The fact that fatigue 
obtenido sea el fallo por fatiga de la armadura, incluso ante casos en los que el hormigón estaba muy solicitado, ha llevado a la conclusión ampliamente aceptada de que la capacidad redistributiva del hormigón es tan grande que es muy improbable que se produzca un fallo por fatiga del hormigón. Es extremadamente complicado encontrar en la literatura una campaña experimental en la que se haya obtenido un fallo por fatiga del hormigón. En este artículo se analiza, sin embargo, una serie de ensayos realizada por el equipo de König en la Universidad de Darmstadt a mediados de los años 80 (14) en las que sí se consiguió este modo de fallo.

Las vigas estaban especialmente diseñadas para buscar, o descartar definitivamente, la posibilidad de que el hormigón rompa por fatiga en vigas sometidas a flexión. Por ello las vigas contenían hormigón de baja resistencia (22 MPa de media), alta cuantía de armadura $(3,49 \%)$ y fueron sometidas a un nivel elevado de la carga (superior al $80 \%$ de la última). El esquema de los ensayos y la sección transversal se dibujan en la Figura 6. Los principales datos de cada ensayo se indican en la Tabla 2. failure has normally been observed to be attributable to the reinforcement, even when the concrete was under substantial stress, has led to the generally accepted conclusion that the capacity to redistribute loads is so large in concrete that fatigue failure is highly unlikely in this material. And indeed, experimental campaigns reporting fatigue failure in concrete are exceptionally rare in the literature. The present article nonetheless analyses a series of trials conducted by König's team at Darmstadt University in the mid-nineteen eighties (14), in which this type of failure was recorded.

The beams were specially designed to either cause fatigue failure in concrete under bending stress, or rule out that possibility altogether. The beams were therefore prepared with low strength (a mean of $22 \mathrm{MPa}$ ) concrete and a high reinforcement ratio (3.49\%) and were heavily loaded (at over $80 \%$ of their ULS). A sketch of the trial set-up and cross-section are shown in Figure 6. The main data for each trial are given in Table 2.

Tabla 2 / Table 2

Datos de los ensayos de Hashem (serie RK).

Main data of tests from Hashem (RK series).

\begin{tabular}{|c|c|c|c|c|c|}
\hline Test & $\boldsymbol{f}_{\boldsymbol{c}}(\mathbf{M P a})$ & $\boldsymbol{P}_{\min }(\mathbf{k N})$ & $\boldsymbol{P}_{\max }(\mathbf{k N})$ & $\boldsymbol{N}_{\boldsymbol{f}}$ & Tipo de fallo / Failure mode \\
\hline RK1 & 23.45 & 20.01 & 120.41 & 7080 & Hormigón / Concrete \\
\hline RK2 & 19.48 & 19.49 & 109.47 & 3360 & Hormigón / Concrete \\
\hline RK3 & 20.54 & 21.70 & 102.93 & 5046000 & Detenido sin rotura / Run-out \\
\hline RK4 & 26.35 & 24.18 & 129.97 & 89870 & Hormigón / Concrete \\
\hline RK5 & 24.46 & 24.50 & 130.29 & 27800 & Hormigón / Concrete \\
\hline RK6 & 23.61 & 22.24 & 124.04 & 1675000 & Acero / Steel \\
\hline RK7 & 23.61 & 23.78 & 124.83 & 476870 & Hormigón / Concrete \\
\hline RK8 & 18.58 & 21.09 & 110.62 & 3940 & Hormigón / Concrete \\
\hline RK9 & 18.32 & 21.14 & 113.35 & 1540 & Hormigón / Concrete \\
\hline
\end{tabular}

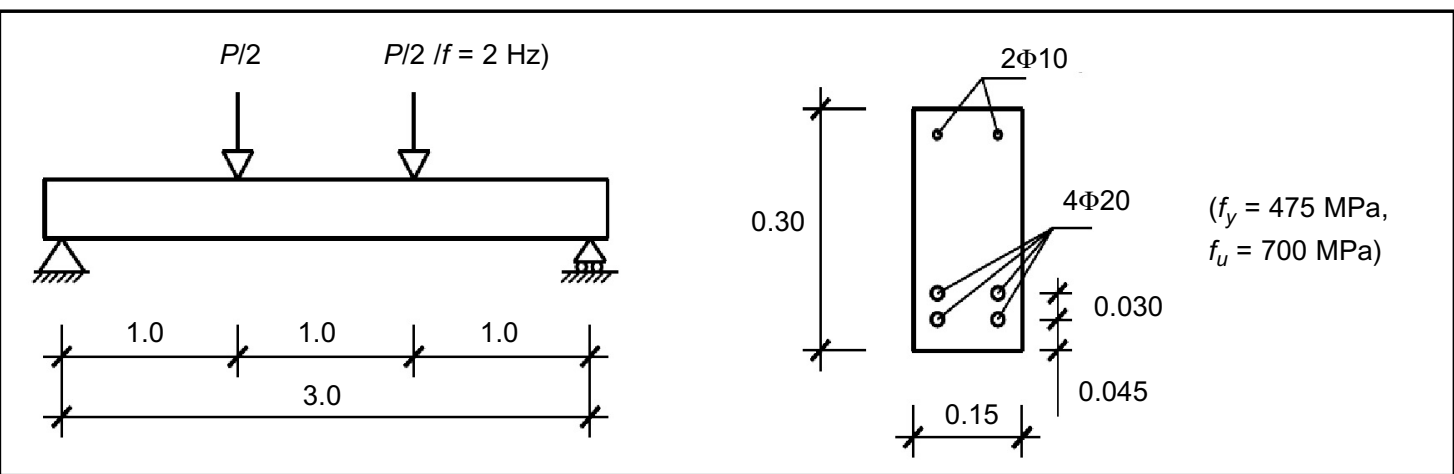

Figura 6. Formato del ensayo y sección transversal (serie RK de Hashem). Dimensiones en $\mathrm{m}$. Figure 6. Test set-up and cross-section (RK series tested by Hashem). Dimensions in $\mathrm{m}$.

Para estudiar la capacidad de predecir la fatiga del hormigón de diferentes modelos disponibles, se puede definir el coeficiente de seguridad de la ecuación [13]:
The safety factor given by equation [13], which can be defined to predict concrete fatigue under the various models in place, 


$$
S F_{i}=\frac{\log N_{\text {test }}}{\log N_{i}}
$$

que relaciona el número de ciclos de rotura experimental y el número de ciclos previsto según el modelo $i$. Así se han evaluado $S F_{Z \prime} S F_{\mathrm{EC} 2}$ y $S F_{\mathrm{MC}}$, siendo:

El coeficiente $S F_{z}$ se obtiene empleando el modelo de fatiga del material explicado en el apartado 2, que se inserta en el método de análisis estructural presentado en (12). Este modelo tiene en cuenta el proceso real de fatiga del hormigón.

El valor $\mathrm{SF}_{\mathrm{EC} 2}$ se obtiene mediante la curva S-N del hormigón del EC2-2 (17) (ecuación [1] y Tabla 1), introduciendo las tensiones en la fibra del hormigón más solicitada en la hipótesis de sección fisurada (estado estático de tensiones).

El coeficiente $S F_{\text {MC90 }}$ se calcula con el número de ciclos dado por la metodología del Código Modelo (18). Este código también emplea una curva S-N para el hormigón (ecuaciones [4], [5], [6]). Sin embargo, las tensiones introducidas en estas ecuaciones son las obtenidas en la fibra más solicitada del hormigón bajo la hipótesis de sección fisurada y multiplicadas por un coeficiente reductor $\eta$. Este factor está basado en la propuesta de König (19) y persigue tener en cuenta de forma simplificada la disminución de las tensiones pésimas por el proceso de redistribución interna. El coeficiente $\eta$ evalúa la capacidad redistributiva del bloque comprimido, de forma que $\eta \sigma_{\max } / f_{c}$ expresa la relación entre la tensión media en el bloque comprimido en servicio y la tensión media en el bloque comprimido en agotamiento. Suponiendo que en esos dos casos la distribución de tensiones en el bloque comprimido es un triángulo y una parábola, respectivamente, se obtiene: is found as the ratio of the log of the experimental number of cycles to failure to the log of the number of cycles predicted in model i. $S F_{Z}, S F_{E C 2}$ and $S F_{M C 90}$ were found from this expression.

Coefficient $\mathrm{SF}_{z}$ was obtained using the material fatigue model described in section 2, which was incorporated into the structural analysis method introduced in an earlier paper (12). This model makes provision for the actual concrete fatigue process.

The $S F_{E C 2}$ value was found with the concrete $S-N$ curve recommended in EC2-2 (17) (Equation [1] and Table 1) in which the stress on the most heavily loaded concrete fibre was the value used and cracked section (static stress state) conditions were assumed.

Coefficient $S F_{M C 90}$ was calculated from the number of cycles, further to Model Code methodology (18). This code also uses an S-N curve for concrete (Equations [4], [5], [6]). Here, however, the stress entered in the equation was the value for the most heavily loaded concrete fibre (assuming a cracked section), multiplied by factor $\eta$. This factor, based on König's proposal (19), is a simplified method for building the decline in maximum stress resulting from internal redistribution into the model. Factor $\eta$ represents the redistributive capacity of the compression member and $\eta \sigma_{\max } / f_{c}$ expresses the ratio between mean stress on the compression member in service and at failure. Assuming that stress is distributed in the form of a triangle in the member in service and of a parabola at failure, the resulting expression is:

$$
\eta \frac{\sigma_{\max }}{f_{c}}=\frac{\frac{1}{2} \sigma_{\max }}{\frac{3}{4} f_{c}}=\frac{2}{3} \frac{\sigma_{\max }}{f_{c}}
$$

Siendo $\sigma_{\max }$ la tensión máxima en servicio. De acuerdo a [14], se obtiene que $\eta=2 / 3$, que es el valor empleado por elódigo Modelo. En la Tabla 3 se comparan los resultados obtenidos para los tres modelos analizados, teniendo en cuenta los resultados experimentales. Hay que destacar que los valores de las tensiones en el hormigón bajo hipótesis de sección fisurada se han calculando suponiendo comportamiento no lineal del hormigón en compresión, a pesar de que tanto el EC2-2 como el MC90 recomiendan asumir comportamiento lineal del hormigón. Esto se ha hecho porque, dado que las cargas aplicadas en las vigas estudiadas son muy elevadas, el cálculo resultaría en tensiones mayores que la resistencia del hormigón.
Where $\sigma_{\max }$ is the maximum in-service stress. Further to Equation [14], $\eta=2 / 3$, which is the value used in the Model Code. Table 3 compares the three models analysed in terms of their ability to predict the experimental results. The cracked section concrete stress values were calculated assuming non-linear behaviour of concrete under compressive stress, even though both EC2-2 and MC90 recommend the contrary. This procedure was chosen because otherwise, due to the very heavy loads on the beams studied, the calculation would have led to stress values higher than concrete strength. 
La Tabla 3 indica que el modelo de fatiga del hormigón propuesto en el apartado 2 da lugar a un valor medio de $S F_{z}=1,330$ (con una desviación estándar de 0,249), lo cual es bastante aceptable, destacando el hecho de que el modelo predice para todos los ensayos un resultado conservador. En cuanto a las predicciones del MC90, se observa que el valor medio de $S F_{\text {MC90 }}$ es más próximo a 1,0 , pero se ve penalizado por el hecho de que su predicción queda del lado de la inseguridad en 4 de las 9 vigas estudiadas. Esto indica que la capacidad redistributiva de estas vigas es menor que la asumida tomando un coeficiente $\eta=2 / 3$. Finalmente, la Tabla 3 muestra que los resultados del EC2-2 son extremadamente conservadores, al no considerar la capacidad redistributiva de la sección. En este sentido, Van Bogaert (20) ha informado que puede darse el caso de puentes ferroviarios que no cumplan los requerimientos del EC2-2 a pesar de llevar muchos años en servicio sin problemas.
As the table shows, the concrete fatigue model proposed in section 2 yields a mean $S F_{z}$ of 1.330 (with a standard deviation of 0.249). This is fairly acceptable, particularly since the prediction for all the trials was conservative. The MC90 predictions showed a mean $S_{M C 90}$ value closer to 1.0, although the predictions erred on the nonsafe side in four of the nine beams studied. This is an indication that the redistributive capacity of these beams was lower than assumed when factor $\eta=2 / 3$. Finally, the findings for EC2-2 were extremely conservative, inasmuch as the cracked section was assumed to be unable to redistribute stress. According to Van Bogaert (20), this may explain why certain railway bridges that fail to comply with EC2-2 have remained in uneventful service for many years.

Tabla 3 / Table 3

Comparación de la vida a fatiga de los ensayos con la de los modelos de Zanuy et al., MC90 y EC2-2. Comparison of the experimental fatigue life with that obtained according to the models by Zanuy et al., MC90 and EC2-2.

\begin{tabular}{|c|c|c|c|c|c|c|}
\hline Test & $N_{z}$ & $S F_{z}$ & $N_{\text {MC90 }}$ & $S F_{M C 90}$ & $N_{\mathrm{EC} 2}$ & $S F_{\mathrm{EC} 2}$ \\
\hline RK1 & 5446 & 1.030 & 11227 & 0.951 & 1.2 & 43.759 \\
\hline RK2 & 1975 & 1.070 & 10885 & 0.874 & 1.2 & 54.722 \\
\hline RK3 & 8840 & 1.698 & 11533 & 1.650 & 1.3 & 61.837 \\
\hline RK4 & 6839 & 1.292 & 11497 & 1.220 & 1.3 & 46.726 \\
\hline RK5 & 3376 & 1.260 & 10914 & 1.101 & 1.2 & 66.841 \\
\hline RK6 & 3871 & 1.735 & 11214 & 1.537 & 1.2 & 71.452 \\
\hline RK7 & 4951 & 1.537 & 11278 & 1.401 & 1.2 & 62.137 \\
\hline RK8 & 919 & 1.213 & 10589 & 0.893 & 1.1 & 82.667 \\
\hline RK9 & 652 & 1.133 & 10707 & 0.791 & 1.1 & 61.386 \\
\hline Media / Average & - & 1.330 & - & 1.157 & - & 61.281 \\
\hline Desv. Estándar / Standard deviation & - & 0.249 & - & 0.295 & - & 11.327 \\
\hline
\end{tabular}

$S F_{i}=\frac{\log N_{\text {test }}}{\log N_{i}}$

Aunque las predicciones más ajustadas a los resultados experimentales son las obtenidas empleando el modelo de fatiga presentado, su aplicación no es inmediata y requiere una tarea de programación no disponible en la práctica ingenieril. Es por ello que se propone una modificación del factor $\eta$ que permita la aplicación del método del Código Modelo de forma más efectiva. Para evaluar la relación entre la solicitación media del bloque comprimido en servicio y en rotura, se propone emplear el valor de $\eta$ de la ecuación [15]:
Although the results that predicted the experimental findings most accurately were obtained with the fatigue model introduced here, the procedure is not readily applicable and calls for engineering software not generally available. Alternatively, an amendment is proposed to factor $\eta$ that allows for more effective application of the Model Code method. The proposal is to use the expression for $\eta$ shown in equation [15] to assess the mean in-service-to-mean at failure stress ratio for compression members:

$$
\eta=\frac{M_{\max }}{M_{u}^{*}}
$$

Siendo $M_{\max }$ el momento flector máximo aplicado y $M_{u}{ }^{*}$ el momento de agotamiento de la sección suponiendo
Where $M_{\max }$ is the maximum bending moment applied and $M_{u}{ }^{*}$ the failure moment in the section, assuming 
comportamiento no lineal del hormigón y comportamiento elástico lineal de la armadura, es decir, la rotura tendrá lugar por la cabeza comprimida. La Tabla 4 muestra el valor del coeficiente de seguridad obtenido para cada ensayo. Aunque la media es superior a la obtenida inicialmente $(2,243$ frente a 1,157$)$, el resultado es conservador para todos los ensayos, sin llegar al extremo de la predicción del EC2-2. non-linear behaviour in the concrete and elastic linear behaviour in the steel: i.e., assuming failure to take place at the compression-stressed head of the member. The safety factor values for each trial are given in Table 4. While the mean was higher than initially obtained (2.243 compared to 1.157), the result was conservative for all trials, although not as extremely so as in the EC22 predictions.

Tabla 4 / Table 4

Vida a fatiga obtenida según el coeficiente $\eta$ modificado.

Fatigue life according to modified parameter $\eta$.

\begin{tabular}{|c|c|c|c|}
\hline Test & $\eta$ & $\boldsymbol{N}_{\text {Mc90 } \text { mod }}$ & $\boldsymbol{S F}_{\text {mod }}$ \\
\hline RK1 & 0.825 & 146 & 1.778 \\
\hline RK2 & 0.836 & 104 & 1.748 \\
\hline RK3 & 0.823 & 157 & 3.053 \\
\hline RK4 & 0.817 & 184 & 2.187 \\
\hline RK5 & 0.830 & 123 & 2.128 \\
\hline RK6 & 0.827 & 138 & 2.911 \\
\hline RK7 & 0.821 & 162 & 1.974 \\
\hline RK8 & 0.851 & 66 & 1.838 \\
\hline RK9 & 0.859 & 54 & 2.243 \\
\hline Media / Average & - & - & 0.462 \\
\hline
\end{tabular}

$S F_{\text {mod }}=\frac{\log N_{\text {test }}}{\log N_{M C 90 \mathrm{mod}}}$

Por otra parte, el modelo de fatiga del hormigón presentado por los autores permite además la obtención de la evolución de deformaciones y tensiones, mientras que los modelos normativos sólo se fijan en la resistencia a fatiga. En la Figura 7 se compara la evolución de la deformación en la fibra más solicitada del hormigón obtenida con el modelo y las medidas tomadas en tres ensayos. Como se observa, la comparación es bastante satisfactoria.
The concrete fatigue model introduced here also provides information on variations in stress and strain, while the models recommended in the standards focus on fatigue strength only. Figure 7 compares the modelcomputed strain on the most heavily loaded concrete fibre to the measurements recorded in three trials. As the figure shows, the results of this comparison are fairly satisfactory.

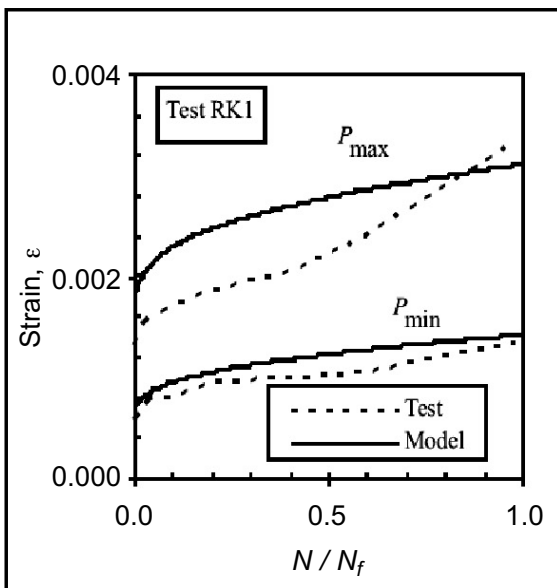

(a)

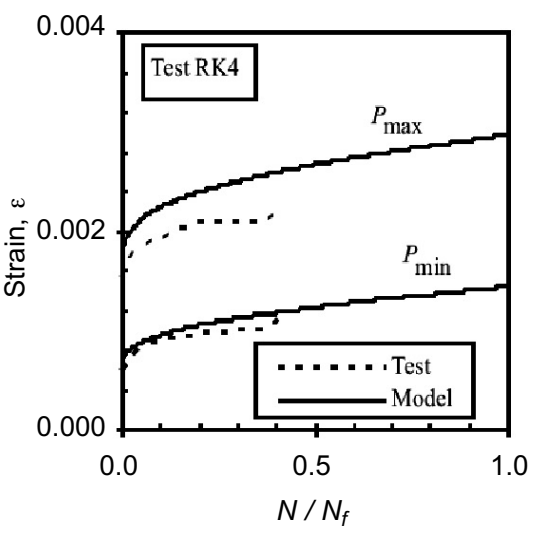

(b)

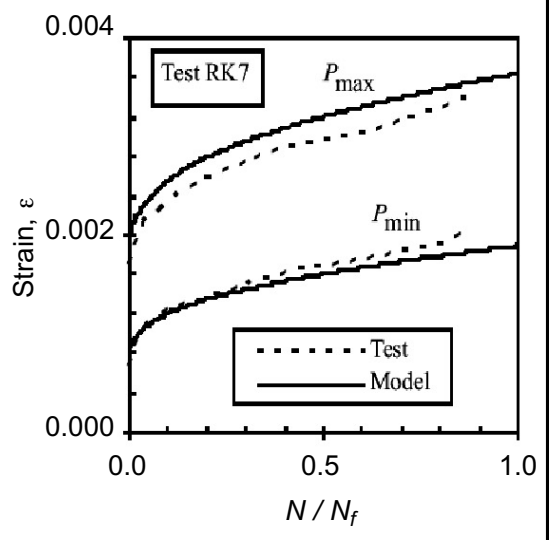

(c)

Figura 7. Comparación de la deformación del hormigón teórica y experimental bajo carga máxima y mínima. Figure 7. Comparison of computed and measured concrete strain under maximum and minimum load. 


\section{CONCLUSIONES}

En este artículo se ha estudiado el proceso de fatiga del hormigón. Se ha indicado que, al contrario que en otros materiales lineales como los metales, el hormigón sufre un progresivo deterioro de sus propiedades mecánicas durante el proceso de fatiga, para las cuales se han propuesto unas leyes de evolución. Este resultado macroscópico es debido a la progresiva microfisuración que sufre el material. Al estudiar la influencia que el proceso de fatiga tiene en el comportamiento de elementos estructurales, se ha visto que la capacidad redistributiva de las estructuras de hormigón armado hace que el número de ciclos resistentes frente a fatiga del hormigón en compresión sea superior al que se obtendría introduciendo las tensiones estáticas en las curvas S-N.

Por esos motivos, los modelos propuestos por las normativas que no tienen en cuenta la capacidad redistributiva de la estructura dan resultados excesivamente conservadores (como el Eurocódigo EC2-2). Para obtener un valor más realista de la vida a fatiga del hormigón se ha propuesto un coeficiente de reducción de las tensiones estáticas modificado con respecto al que utiliza el Código Modelo. Este procedimiento simplificado permite evaluar de una manera simple la resistencia a fatiga del hormigón en la práctica ingenieril.

En caso de necesitarse una estimación más ajustada de la vida a fatiga del hormigón, o para determinar la evolución de tensiones y deformaciones (y por tanto movimientos) de una estructura de hormigón durante su vida a fatiga, es necesario emplear un modelo de fatiga del hormigón como el indicado por los autores en el presente artículo.

\section{CONCLUSIONS}

This article studies concrete fatigue. Contrary to materials such as metals whose fatigue behaviour is linear, in concrete the mechanical properties deteriorate gradually during fatigue; a series of laws are proposed to describe these changes. The macroscopic result is due to progressive microcracking. This study of the effect of fatigue on structural member behaviour shows that as a result of load redistribution in reinforced concrete structures, the actual number of cycles to failure in concrete under compressive stress is higher than found with $S-N$ curves plotted using static stress values.

This explains why the models proposed by standards that fail to take this redistributive capacity into consideration (such as Eurocode EC2-2) yield overly conservative results. $A$ factor that reduces static stress, an amended version of the factor used in the Model Code, is therefore proposed to calculate the fatigue life of concrete more realistically. This simplified procedure constitutes a method for readily assessing concrete fatigue strength in everyday engineering practice.

More accurate estimates of concrete fatigue life, however, or determinations of stress and strain variations (and therefore movement) in a concrete structure during its fatigue life, call for a more fully developed fatigue model such as described in this article.

\section{BIBLIOGRAFÍA / BIBLIOGRAPHY}

(1) Paris, P.; Erdogan, F.: "A critical analysis of crack propagation laws", Journal Basic Engineering (1963), pp. 528-534.

(2) Mu, B.; Subramaniam, K.V.; Shah, S. P.: "Failure mechanism of concrete under fatigue compressive load", J. Mater. Civil Eng., vol. 16, no 6 (2004), pp. 566-572. doi:10.1061/(ASCE)0899-1561(2004)16:6(566)

(3) Bennett, E. W.; Raju, N. K.: "Cumulative fatigue damage of plain concrete in compression", International conference on structures, solid mechanics and engineering design in Civil Engineering materials, University of Southampton (1969), pp. 1089-1101.

(4) Shah, S. P.; Chandra, S.: "Fracture of concrete subjected to cyclic and sustained loading", ACI J., vol. 67-49 (1970), pp. 816-825.

(5) Hsu, T. T. C.: "Fatigue of plain concrete", ACI J., vol. 78, no 4 (1981), pp. 292-305.

(6) Petkovic, G.; Lenschow, R.; Stemland, H.; Rosseland, S.: "Fatigue of high strength concrete", ACI SP 121-25 (1990), pp. 505-525.

(7) Zanuy, C.: Análisis seccional de elementos de hormigón armados sometidos a fatiga, incluyendo secciones entre fisuras, PhD Thesis, Universidad Politécnica de Madrid, p. 251 (2008). Disponible en: http://oa.upm.es/1158/.

(8) Park, Y. J.: "Fatigue of concrete under random loadings", J. Struct. Eng.-ASCE, vol. 116, no 11 (1990), pp. $3228-3235$. doi:10.1061/(ASCE)0733-9445(1990)116:11(3228)

(9) Holmen, J. O.: Fatigue of concrete by constant and variable amplitude loading, PhD Thesis, University of Trondheim, Norway (1979).

(10) Hohberg, R.: Zum Ermüdungsverhalten von Beton, PhD Thesis, Univ. Berlin, p. 91 (2004).

(11) Miner, M. A.: "Cumulative damage in fatigue", Transactions ASME, Journal of Applied Mechanics, vol. 67 (1945), p. A 159.

(12) Zanuy, C.; Albajar, L.; de la Fuente, P.: "Sectional analysis of concrete structures under fatigue loading", ACI Struct. J., vol. 106, n० 5 (2009), pp. 667-677. 
(13) Hilsdorf, H. K.; Kesler, C. E.: "Fatigue strength of concrete under varying flexural stresses", Journal of the American Concrete Institute, Proceedings, vol. 63, no 10 (1966), pp. 1059-1076.

(14) Hashem, M.: Betriebsfestigkeitsnachweis von biegebeanspruchten Stahlbetonbauteilen, PhD Thesis, Technische Universität Darmstadt, p. 112 (1986).

(15) Schläfli, M.; Brühwiler, E.: "Fatigue of existing reinforced concrete bridge deck slabs", Eng. Struct., vol. 20, n 11 (1998), pp. $991-$ 998. doi:10.1016/S0141-0296(97)00194-6

(16) Kuryllo, A.; Kwascha, W.; Lewschitsch, W.: "Versuche über das Verhalten auf Biegung beanspruchter Stahlbeton - Bauteile unter häufig wiederholter Belastung", Beton und Stahlbetonbau, vol. 4 / 1976 (1976), pp. 103-106.

(17) CEN: Eurocode 2. Part 2. EC2-2. Concrete bridges. Design and detiling rules. prEN 1992-2, p. 90, Brussels, Belgium (1992).

(18) CEB - FIP: CEB - FIP Model Code (1990), Lausanne (Switzerland) (1991).

(19) König, G.; Danielewicz, I.: Ermüdungsfestigkeit von Stahlbeton- und Spannbetonbauteilen mit Erläuterungen zu den Nachweisen gemäss CEB-FIP Model-Code 1990, Deutscher Ausschuss für Stahlbeton. Heft 439, Berlin (1994).

(20) Van Bogaert, P.: "Fatigue due to concrete compression in bridges compared to practice", fib International Symposium, London, UK (2009).

(21) Kim, J. K.; Kim, Y. Y.: "Experimental study of the fatigue behavior of high strength concrete", Cement Conc. Res., vol. 26, no 10 (1996), pp. 1513-1523. doi:10.1016/0008-8846(96)00151-2

(22) Do, M. T.; Chaallal, O.; Aitcin, P.-C.: "Fatigue behavior of high performance concrete", J. Mater. Civil Eng., vol. 5, no 1 (1993), pp. 96-110. doi:10.1061/(ASCE)0899-1561(1993)5:1(96)

(23) Awad, M. E.; Hilsdorf, H. K.: Strength and deformation characteristics of plain concrete subjected to high repeated and sustained loads, University of Illinois, Urbana, Illinois (1971).

(24) Klausen, D.: Festigkeit und Schädigung von Beton bei häufig wiederholter Beanspruchung, PhD Thesis, Universität Darmstadt, p. 85 (1978).

(25) Ople, F. S.; Hulsbos, C. L.: "Probable fatigue life of plain concrete with stress gradient", ACI J., vol. 63, no 1 (1966), pp. 59-82.

(26) Aas-Jakobsen, K.: Fatigue of concrete beams and columns, PhD Thesis, University of Trondheim, p. 148 (1970).

(27) Tepfers, R.; Kutti, T.: "Fatigue strength of plain, ordinary, and lightweight concrete", ACI J., vol. 76, no 5 (1979), pp. 635-652.

(28) Zhang, B.; Phillips, D. V.; Wu, K.: "Efects of loading frequency and stress reversal on fatigue life of plain concrete", Mag. Concrete Res., vol. 48, nº 177 (1996), pp. 361-375. doi:10.1680/macr.1996.48.177.361 